\title{
Pemberdayaan guru paud RA Al-Ghifari Sukabirus Dayeuhkolot dalam penyusunan bahan ajar berbasis online
}

\author{
Vera Suryani", Bayu Erfianto, Andrian Rakhmatsyah \\ Fakultas Informatika, Universitas Telkom \\ Email Korespondensi : *verasuryani@ telkomuniversity.ac.id
}

Received December 10, 2020; Revised March 5, 2021; Accepted June 8, 2021

\begin{abstract}
Abstrak
Kasus Corona Virus Disease 2019 (Covid-19) yang semakin meningkat mengharuskan proses kegiatan belajar mengajar bagi peserta didik untuk sementara waktu dilakukan di rumah. PAUD dan TK Al-Ghifari Sukabirus merupakan salah satu sekolah yang terkena dampaknya. Saat ini, proses kegiatan belajar mengajar masih menggunakan metode konvensional, yaitu hanya pemberian tugas offline kerumah siswa. Pembelajaran tidak efektif untuk siswa dikarenakan tidak ada kegiatan mengajar secara tatap muka oleh guru kepada siswanya. Beberapa guru juga belum terlalu familiar dengan penggunaan media pembelajaran daring, seperti Google Meet maupun Google Classroom . Dengan demikian diperlukan suatu cara transfer knowledge penggunaan media daring yang dapat mendukung proses belajar mengajar di PAUD dan TK Al Ghifari. Tujuan kegiatan pengabdian masyarakat ini ialah mendukung pembelajaran jarak jauh dengan media daring (dalam jaringan) dengan melakukan penyuluhan kepada guru PAUD dan TK Al-Ghifari Sukabirus mengenai cara pembelajaran online menggunakan aplikasi Google Meet, Google Classroom, dan penyusunan bahan ajar berbasis online.
\end{abstract}

Kata Kunci: Google Meet; Google Classroom; PAUD TK Al Ghiffari

\begin{abstract}
The increasing case of Corona Virus Disease 2019 (Covid-19) requires the teaching and learning process for students to be temporarily carried out at home. RA Al-Ghifari Sukabirus is one of the schools affected. Currently, the process of teaching and learning activities is still using conventional methods, namely only giving offline assignments to students. This learning method is insufficient because there are no direct teaching activities between teacher and students. Some teachers are also not too familiar with the use of online learning media, such as Google Meet nor Google Classroom. Thus, we need a way of transferring knowledge using online media that can support the direct teaching and learning process at Al Ghifari Kindergarten. The purpose of this community service activity is to support distance learning by providing counseling to RA AlGhifari Sukabirus teachers about how to use online teaching tools, namely Google Meet and Google Classroom applications. It also teach the teacher how to prepare the teaching materials using these tools.

Keywords : Google Meet; Google Classroom; PAUD TK Al Ghiffari
\end{abstract}

\section{PENDAHULUAN}

Pendidikan Taman Kanak-Kanak merupakan salah satu bentuk pendidikan pra sekolah yang terdapat di jalur pendidikan sekolah (PP No. 27 Tahun 1990). Sebagai lembaga pendidikan pra-sekolah, tugas utama Taman Kanak-Kanak adalah mempersiapkan anak dengan memperkenalkan berbagai pengetahuan, sikap perilaku, keterampilan dan intelektual agar dapat melakukan adaptasi dengan kegiatan belajar yang sesungguhnya di Sekolah Dasar.

Merebaknya kasus pandemi Corona Virus Disease 2019 (Covid-19) sejak Desember 2019 sampai saat ini mengharuskan semua proses kegiatan belajar mengajar bagi peserta didik untuk sementara waktu dilakukan di rumah. Hal itu perlu dilakukan guna meminimalisir kontak fisik secara massal sehingga dapat memutus mata rantai penyebaran virus tersebut.

Banyak sekolah yang harus mengubah proses belajar mengajarnya akibat adanya pandemi ini [1]-[6]. Dari yang awalnya tatap muka, harus beralih ke daring [7][8]. Beberapa sekolah sudah siap dengan perubahan ini oleh karena sistem informasi yang tersedia sebelum masa pandemi. Namun beberapa sekolah yang belum memiliki sistem informasi yang memadai terpaksa harus beradaptasi dengan perubahan ini.

Perangkat bantu pembelajaran daring menjadi primadona, terutama yang bersifat tidak berbayar. Google classroom dan google meet merupakan dua aplikasi atau sistem informasi yang banyak digunakan karena mudah penggunaannya dan tidak berbayar. 
RA Al-Ghifari Sukabirus merupakan salah satu sekolah yang terkena dampak pandemi Corona Virus Disease 2019 (Covid-19) ini. Selama pandemi, proses kegiatan belajar mengajar masih menggunakan metode konvensional, yaitu pemberian tugas kerumah siswa. Oleh karena itu diperlukan penyuluhan untuk pengajaran jarak jauh dengan media daring (dalam jaringan) bagi siswa di sekolah tersebut. Adapun perangkat bantu pembelajaran menggunakan Google classroom dan google meet [9][10].

\section{METODE}

Peninjauan lapangan di TK AL Ghiffari dilakukan untuk mengetahui user requirement dari target sasar pelaksanaan pengabdian masyarakat.

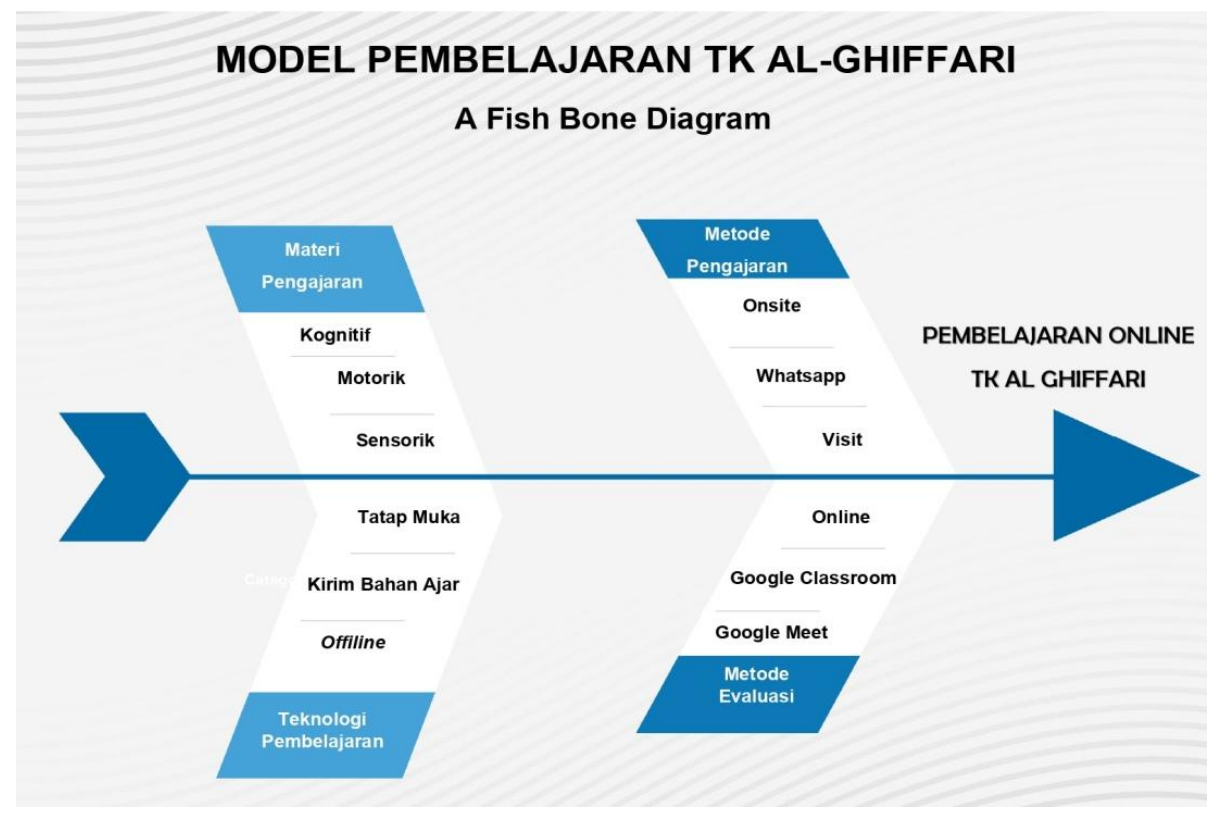

Gambar 1. Diagram fish bone kegiatan PkM

Hasil dari kegiatan peninjauan di gambarkan pada Gambar 1. Selama ini kegiatan belajar mengajar dilaksanakan dengan cara onsite atau ke sekolah, tugas belajar dikirimkan ke rumah, dan tugas dikumpulkan kembali ke sekolah. Hal ini agak berbahaya mengingat selama pandemi sebaiknya mengurangi acara kumpulkumpul. Oleh karena itu, dirumuskan kegiatan pembelajaran online untuk TK Al Ghiffari.

Dalam kegiatan ini dilaksanakan dalam 3 (tiga) metode yaitu :

a. Penyuluhan kepada guru RA Al-Ghifari Sukabirus mengenai cara pembelajaran online dan penyusunan bahan ajar berbasis Online menggunakan aplikasi Google Classroom dan Google Meet.

b. Praktik menggunakan aplikasi Google Classroom dan Google Meet.

c. Evaluasi Pelaksanaan

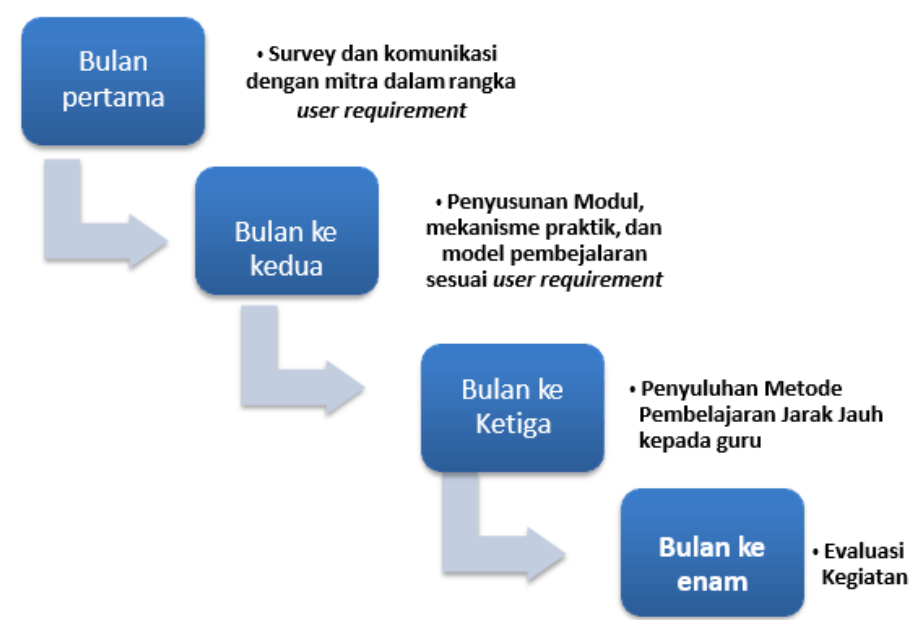

Gambar 2. Roadmap Kegiatan 
Kegiatan pengabdian masyarakat dilaksanakan secara bertahap dalam waktu 6 bulan, seperti terlihat pada Gambar 2. Bulan pertama melakukan survey dan komunikasi dengan mitra dalam rangka user requirement. Bulan kedua melakukan penyusunan Modul, mekanisme praktik dan model pembelajaran sesuai user requirement. Bulan ketiga melakukan penyuluhan metode pembelajaran jarak jauh. Bulan keempat melakukan evaluasi kegiatan. Bulan ke lima dan ke enam penyusunan laporan. Adapun luaran IPTEK yang diharapkan dapat dilihat pada Gambar 3.

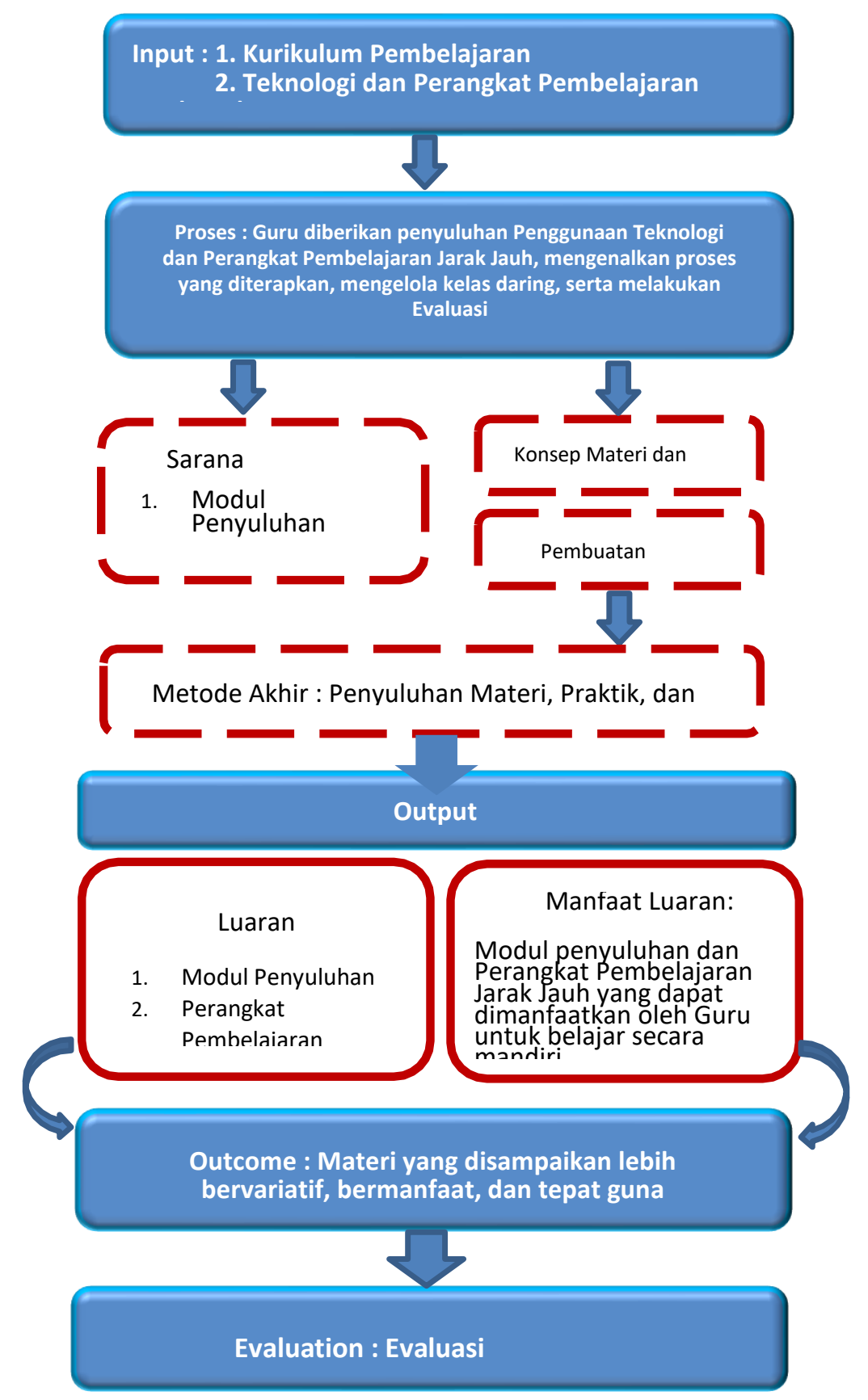

Gambar 3. Gambaran Iptek yang Disalurkan 


\section{HASIL DAN PEMBAHASAN}

Solusi yang ditawarkan ialah pemanfaatan pembelajaran jarak jauh dengan aplikasi Google Classroom dan Google Meet. Kedua aplikasi ini bersifat gratis, sehingga mempermudah guru dalam mengisi kegiatan belajar mengajar pada masa pandemi Corona Virus Disease 2019 (Covid-19) ini. Pembelajaran dapat menggunakan media ponsel, PC, atau laptop.

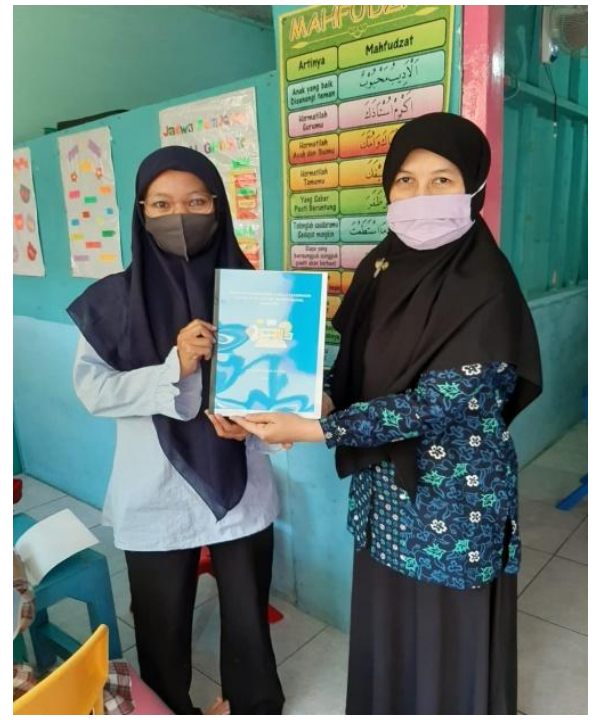

Gambar 4. Penyerahan Modul Penyuluhan
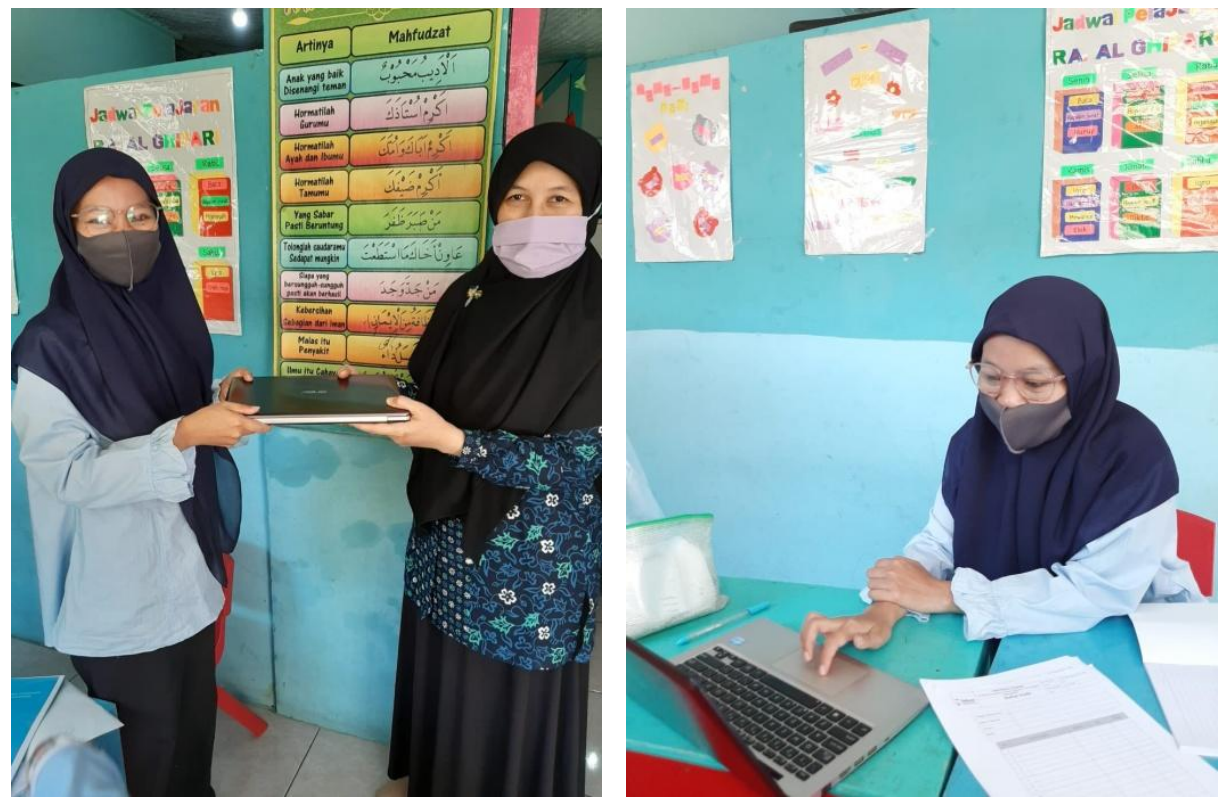

Gambar 5. Penyerahan Perangkat Pembelajaran berupa Laptop

Kegiatan pengabdian masyakarat ini menghasilkan 2 keluaran yaitu Modul Penyuluhan, dan Perangkat Pembelajaran. Modul penyuluhan dan perangkat pembelajaran dapat dimanfaatkan oleh guru untuk belajar secara mandiri. Penyerahan perangkat dan modul terkait penggunaan aplikasi Google Meet dan Google Classroom dapat dilihat pada Gambar 4 dan 5. Sedangkan dokumentasi penyuluhan tatacara penggunaan aplikasi Google Meet dan Google Classroom dapat ditemukan pada Gambar 6. 

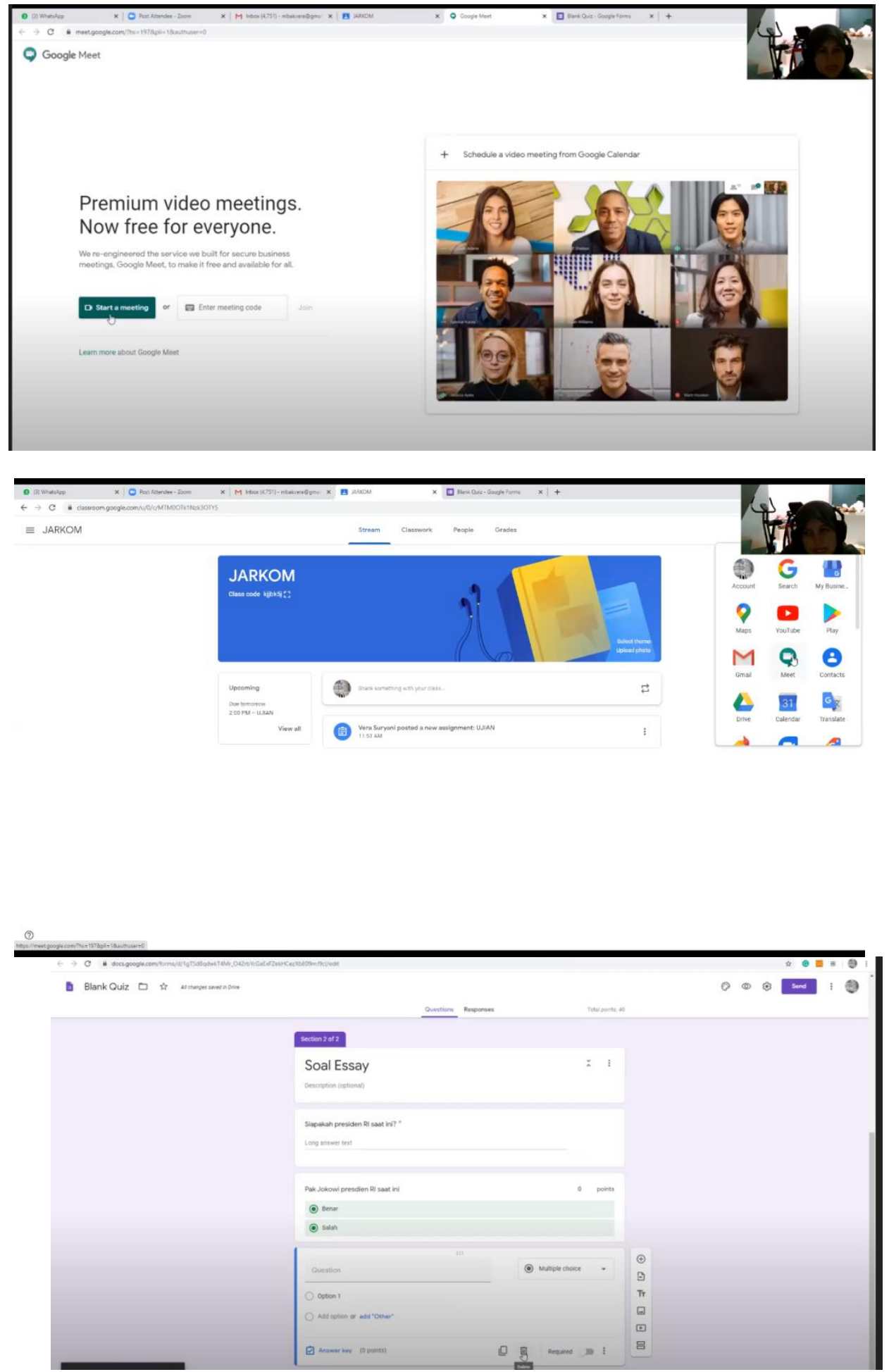

Gambar 6. Dokumentasi Kegiatan Pelatihan Penggunaan Google Classroom dan Google Meet

Survei kepuasan mitra pengabdian masyarakat dilaksanakan untuk melihat feedback dari pelaksanaan kegiatan ini. Hasil survei dapat dilihat pada Tabel 1. 
Tabel 1. Hasil survei kepuasan mitra PkM

\begin{tabular}{|c|c|c|c|c|c|}
\hline \multirow[t]{2}{*}{ Penilaian Terhadap Kegiatan } & \multicolumn{5}{|c|}{ Jumlah masing-masing Faktor yang Dipentingkan } \\
\hline & $\begin{array}{l}\text { Sangat Tdk } \\
\text { setuju }\end{array}$ & Tdk Setuju & Setuju & $\begin{array}{l}\text { Sangat } \\
\text { setuju }\end{array}$ & Total \\
\hline 1. Sesuai dengan tujuan & 0 & 0 & 11 & 29 & 40 \\
\hline 2. Sesuai dengan kebutuhan & 0 & 0 & 10 & 30 & 40 \\
\hline 3. Waktu memenuhi kebutuhan & 0 & 5 & 17 & 18 & 40 \\
\hline 4. Ramah, cepat tanggap & 0 & 0 & 15 & 25 & 40 \\
\hline $\begin{array}{l}\text { 5. Menerima dan mengharapkan } \\
\text { pengmas }\end{array}$ & 0 & 0 & 20 & 20 & 40 \\
\hline Jumlah & 0 & 5 & 73 & 122 & \\
\hline Persentase & $0 \%$ & $3 \%$ & $37 \%$ & $61 \%$ & \\
\hline Jumlah \% setuju+sangat setuju & & & & $97,5 \%$ & \\
\hline
\end{tabular}

Dari hasil survei didapatkan kesimpulan bahwa tingkat kepuasan mitra PkM terhadap proses transfer pengetahuan maupun perangkat bantu pembelajaran daring sangat memuaskan. Hal ini membuka kesempatan untuk tindak lanjut kegiatan PkM lain yang sesuai dengan kebutuhan mitra.

\section{KESIMPULAN}

Kegiatan pengabdian kepada masyarakat ini dapat meningkatkan pemahaman guru mengenai pembelajaran jarak jauh dengan media daring (dalam jaringan). Kegiatan ini juga dapat mempermudah guru melakukan penyusunan bahan ajar secara Online. Melalui aplikasi Google Meet dan Google Classroom, guru dapat berkomunikasi dengan siswa untuk mendukung pembelajaran jarak jauh dimasa pandemi ini.

\section{DAFTAR PUSTAKA}

[1] M. Agustin, R. D. Puspita, D. Nurinten, and H. Nafiqoh, "Tipikal Kendala Guru PAUD dalam Mengajar pada Masa Pandemi Covid 19 dan Implikasinya," J. Obs. J. Pendidik. Anak Usia Dini, vol. 5, no. 1, p. 334, 2020.

[2] A. Hapsari, R. Novitasari, and H. Wahyuningsih, "Pelatihan Literasi Sumber dan Bahan Belajar di Internet bagi Guru PAUD di Kecamatan Ngaglik, Sleman," J. Pengabdi. Pada Masy., vol. 3, no. 2, pp. 135-140, 2018.

[3] M. Qadafi, "Pembelajaran Bahasa Inggris pada Anak di Sangkhom Islam Wittaya School saat Pandemi Covid-19," J. Obs. J. Pendidik. Anak Usia Dini, vol. 5, no. 1, p. 422, 2020.

[4] V. D. Wicaksono and P. Rachmadyanti, "Pembelajaran Blended Learning melalui Google Classroom di Sekolah Dasar," Semin. Nas. Pendidik. PGSD UMS HDPGSDI Wil. Timur, pp. 513-521, 2016.

[5] N. K. S. Astini, "Pemanfaatan Teknologi Informasi dalam Pembelajaran Tingkat Sekolah Dasar pada Masa Pandemi Covid-19,” J. Lemb. Penjaminan Mutu STKIP Agama Hindu Amlapura, vol. 11, no. 2, pp. 13-25, 2020.

[6] Soni et al., "Optimalisasi Pemanfaatan Google Classroom Sebagai Media Pembelajaran Di SMK Negeri 1 Bangkinang," J. Pengabdi. Untuk Mu NegeRI, vol. 2, no. 1, pp. 17-20, 2018.

[7] M. S. Hanip Pujiati, Azizah Muis, Tita, Diana, "Membangun Keterlibatan Orang Tua Dalam Pembelajaran Bahasa Inggris Di Paud Melalui Aplikasi Google Classroom Di Kecamatan Cibinong, Kabupaten Bogor,” in Seminar Nasional Pendidikan, 2018, pp. 124-127.

[8] L. A. Ellyandhani, "Pengaruh Model Blended Learning Berbantu Google Classroom Terhadap Kemampuan Berpikir Kreatif Dan Kemandirian Belajar Peserta Didik Kelas Xi Mata Pelajaran Biologi Di SMA AL-Azhar 3 Bandar Lampung", 2019.

[9] I. N. M. Shaharanee, J. M. Jamil, and S. S. M. Rodzi, "Google classroom as a tool for active learning," in AIP Conference Proceedings, 2016, vol. 1761.

[10] S. Iftakhar, "GOOGLE CLASSROOM: WHAT WORKS AND HOW?,” J. Educ. Soc. Sci., vol. 3, pp. 1-17, 2020. 